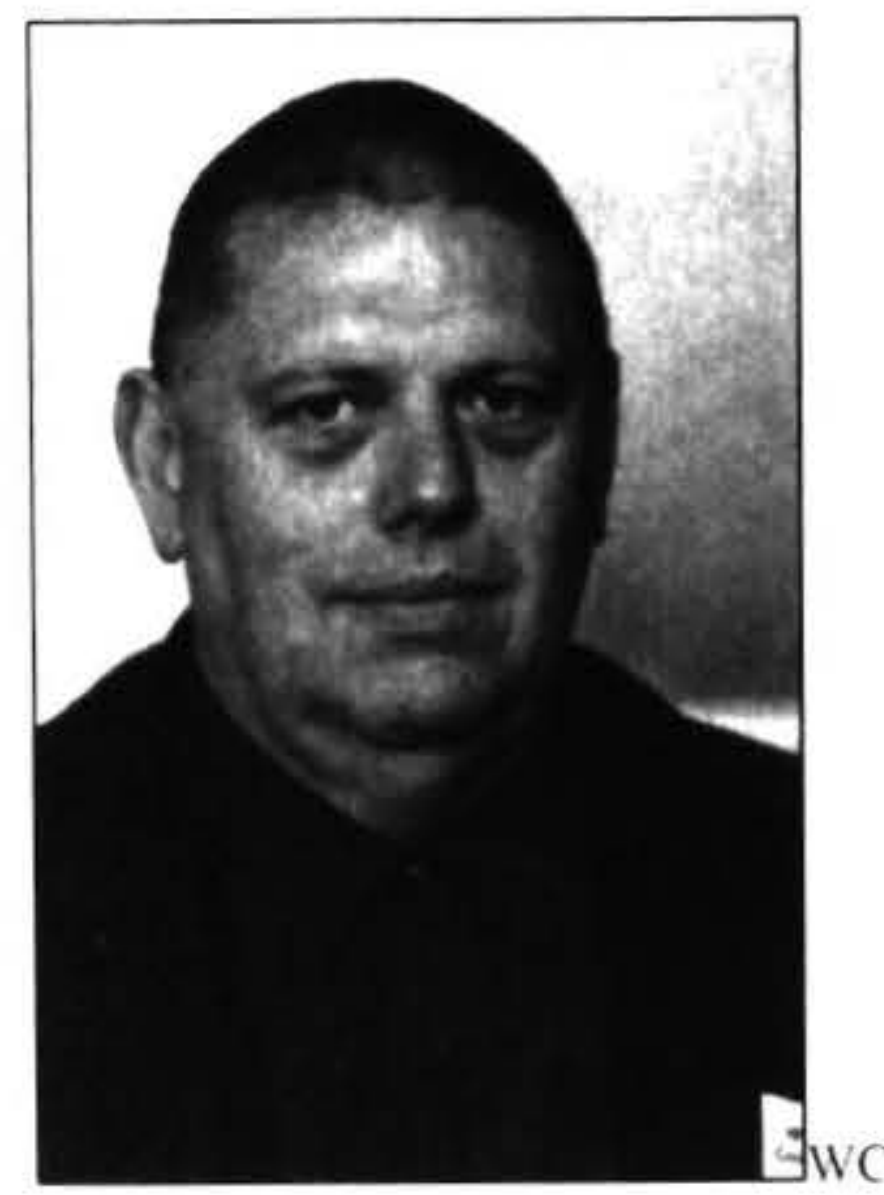

\title{
HOMEOWNERSHIP AND THE NEW ZEALAND LABOUR MARKET
}

\author{
William Cochrane \\ Population Studies Centre, University of \\ Waikato, Hamilton \\ Jacques Poot \\ Population Studies Centre, University of \\ Waikato, Hamilton
}

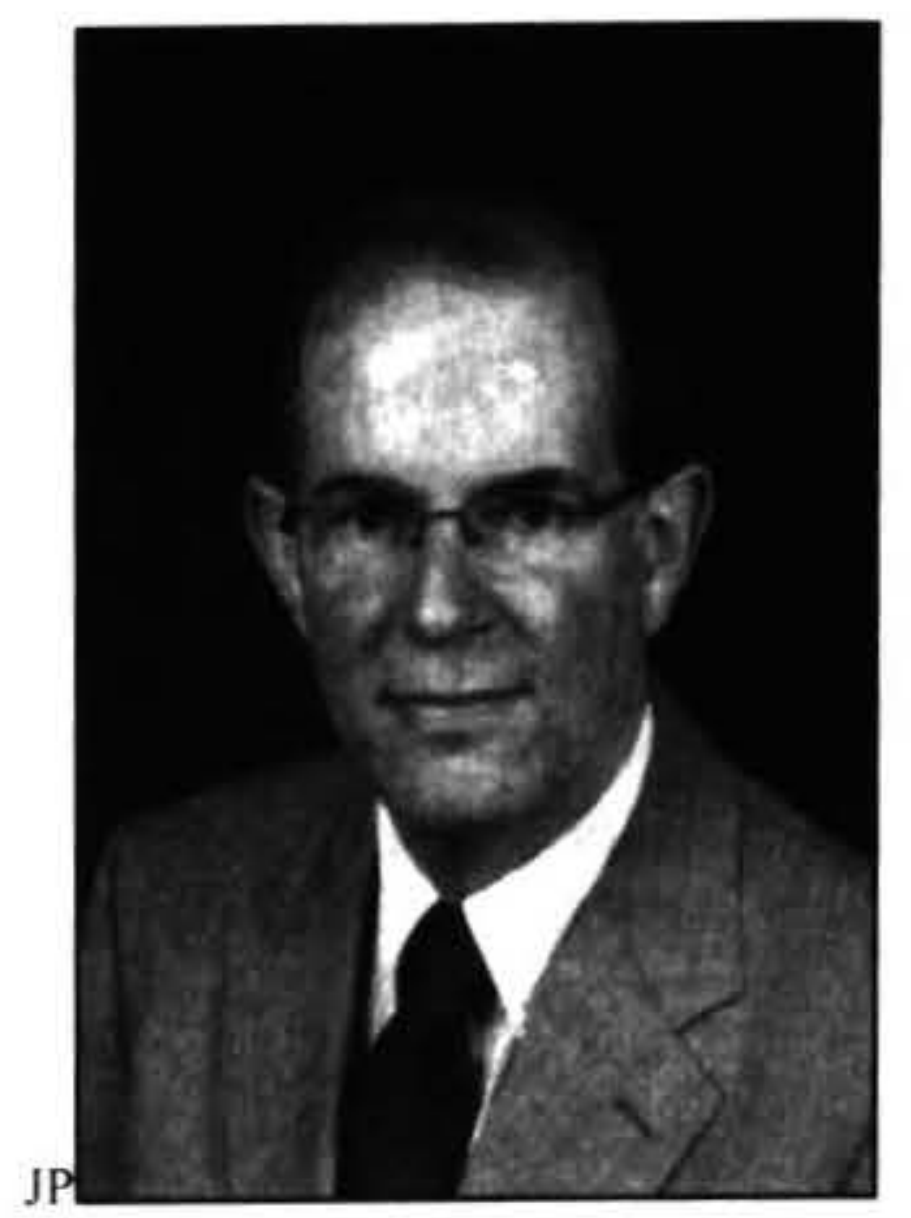

Abstract

Since the early 1990s, the proportion of the New Zealand households living in owner-occupied dwellings has declined markedly fiom 73.8 percent in 1991 to 66.9 percent in 2006. Over the same period there has been a decline in the unemployment rate from 10.5 percent to 3.5 percent. Several demand. supply and institutional factors are responsible for the dowmward trend in unemplosment. hut this paper investigates a possible connection with homeownership that has hitherto not been investigated in New Zealand. Andrew Oswald argued in a series of unpublished papers in the 1990s that home ownership is detrimental to lahour market flexibility because of transaction costs that home owners must incur when a job change necessitates a change of residence. An extensive theoretical and empirical literature on this hrpothesis has emerged internationally: The present paper reviews earlier findings and then tests the hypothesis with 1986. 1991. 1996 and 2001 census data for 58 labour market areas, using econometric models for panel data. We take account of the endogeneity of homeosnership. The New Zealand models do provide evidence that supports the Oswald hypothesis.

\section{Introduction}

Two decades ago New Zealand was on a path of radical economic liberalisation that led to a significant restructuring and transformation of the economy. It was inevitable that such change would lead to massive job losses, particularly in the previously protected manufacturing sector, and a mismatch between job seckers and any jobs created in the transformation process. As can be seen from Figure I, the unemployment rate measured by the Household Labour Force Survey peaked at 11 percent by 1991 and the NZ Government at the time responded by extending the economic reforms to the labour market through the introduction of the Employment Contracts Act (ECA) which promoted individual contracts and weakened the scope of collective bargaining and the power of trade unions. Subsequently, unemployment declined markedly and widely eited reviews of the reforms such as Evans et al. (1996) attributed this in part to the success of the ECA in enhancing labour market flexibility. A formal assessment of the impact of labour market reforms is actually easier said than done (Gorter and Poot, 1999). There are a multitude of consequences, some positive and some negative. Causal linkages are easier to conjecture than to quantify econometrically. However, there is little disagreement that the economic reforms, including the ECA and external economic forces, such as globalisation. contributed to growing income inequality, lesser social cohesion and increasing vulnerability of certain regions and population groups throughout the 1990s. This led to a political change of direction following the 1999 election of a left of centre coalition government and to various "corrections" to the reforms, including new labour relations legislation in the form of the Employment Relations Act (ERA) that provided greater scope for collective bargaining and worker protection. The unemployment rate continued to fall this time of reintroduction of somewhat greater regulation of the labour market, coinciding with rather buoyant economic conditions since the new millennium.

One trend that has coincided with the long-run decline in the unemployment rate since the early 1990s is a long-run decline in the rate of homeownership, at least in terms of owner-occupied dwellings. The number of persons owning one or more rental properties has actually increased but the proportion of the NZ households living in owner occupied dwellings has declined from a little less than 74 percent in 1986 and 1991, to 70.5 percent in $1996,67.8$ percent in 2001 and 66.9 percent in 2006. This is also shown in Figure 1 , in which the census rates are applied to five-year periods centred on census dates. There are several reasons for the decline in homeownership, but the main one is the decline in affordability of ownership due to rapidly rising house prices and relatively high interest rates. At the same time, real rents declined as landlords anticipated returns from capital gains rather than rental revenue. Growing 
inequality also put homéwnership out of reach of those on low incomes.

In a series of working papers and a letter to the Journal of Economic Perspectives written in the late 1990s, Andrew Oswald (1996; 1997a; 1997b; 1999) argues that a high rate of homeownership increases the natural rate of unemployment because the transaction costs associated with relocation discourage workers from seeking employment outside their commuting area. Conversely, following this argument, the decline in NZ homeownership since the 1980s would have increased geographic mobility and labour market flexibility, contributing to the decline in the long-term rate of unemployment. Certainly, geographic mobility has increased. Less than half of the population changed residence at least once during a five-year intercensal period in the 1980s. By 2001, this increased to 55.4 percent and further to 57.7 percent in 2006 .

There has not been any formal assessment in New Zealand of a possible link between homeownership and unemployment, despite Oswald's hypothesis having generated a large volume of literature in other countries. Skilling (2004: 19) refers to this hypothesis in a paper that advocates more widespread asset ownership among the New Zealand population, including of dwellings, but then downplays the possibility of homeownership having what he calls a "dark side" in terms of generating unemployment by referring to US evidence by Glaeser and Shapiro (2002) and Australian evidence by Flatau et al. (2002) that does not appear consistent with the Oswald hypothesis. Indirectly, some NZ econometric modelling by Maré and Timmins (2004) also contradicts the Oswald claim. Maré and Timmins estimate the responsiveness of the number of migrants to relative employment conditions in origin and destination regions and then interact this effect with homeownership rates. They find that responsiveness to relative employment performance is greater when more homes are owner-occupied, which is the opposite of what the Oswald hypothesis would suggest. However, their model analyses the spatial variation in mobility rates rather than unemployment rates per se.

The purpose of this paper is to investigate the Oswald hypothesis directly using a panel of observations on New Zealand labour market areas from 1986 to 2001. Having only access to grouped data, there are limitations to the extent to which the available data can test the hypothesis, but the uses of a panel ameliorates to some extent the missing variables bias that is likely to affect a purely cross-sectional analysis. Also, we will take the possible two-way causality between homeownership and unemployment into account by means of panel estimators that account for endogenous regressors.

Figure 1: New Zealand unemployment rate and home ownership rate 1986-2006.

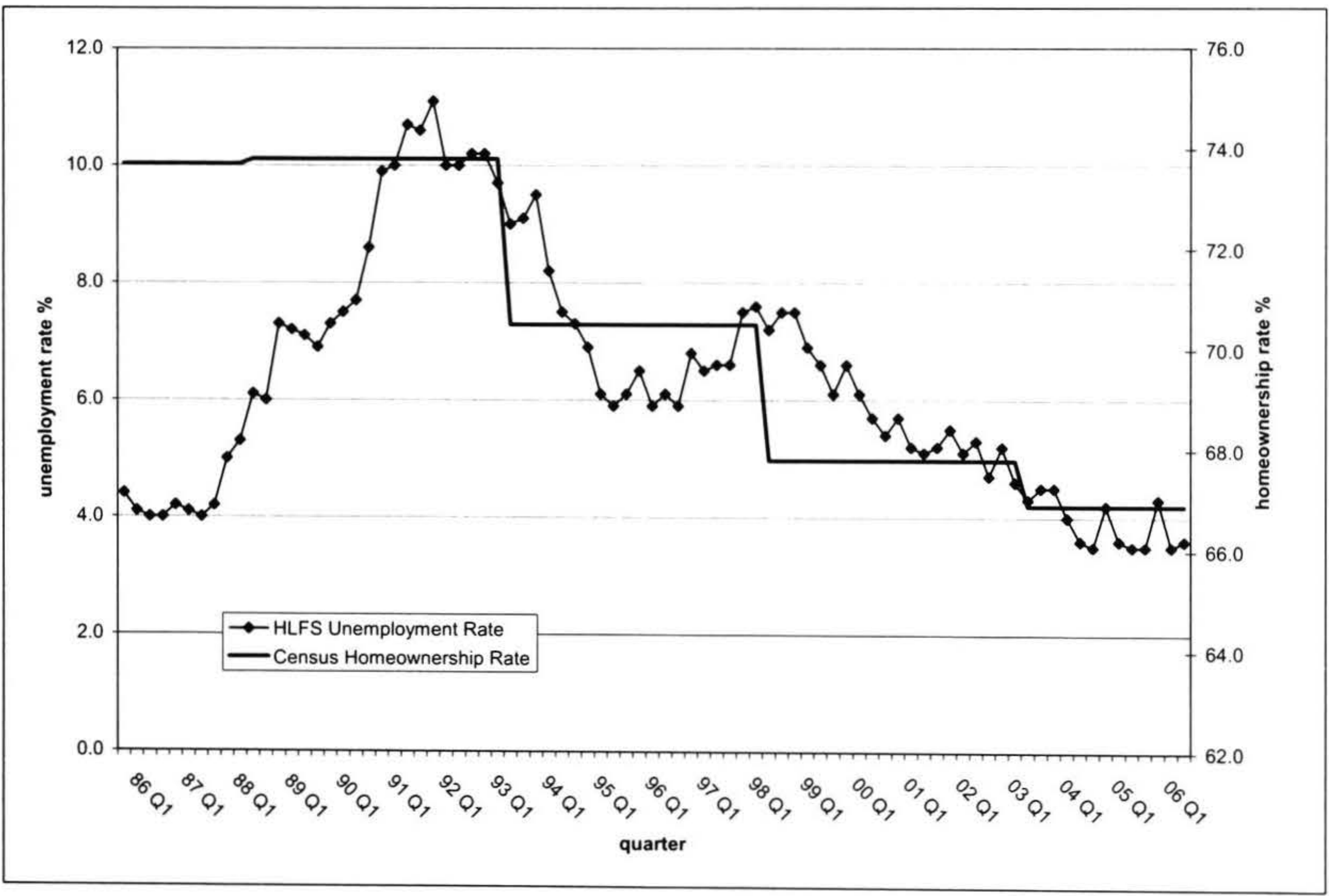

Source: Statistics New Zealand, Household Labour Force Survey and Census of Population and Dwellings. 


\section{A Short Review of the Literature}

In a background paper written for his 1997 inaugural lecture, Andrew Oswald posits that the increase in homeownership in several European countries is an important cause of the upward trend in the unemployment rate in those countries (Oswald, 1996). He argues that the primary reason is that homeowners are geographically less mobile and that an increase in the proportion of the population living in owner-occupied dwellings could therefore lead to less labour market flexibility and higher unemployment.

As the empirical evidence about this hypothesis to date has already been reviewed before (e.g., recently: Munch et al. 2006: Rouwendal and Nijkamp, 2006), we can remain brief here and suggest some causes of apparently contradicting evidence.

There would be general agreement that geographic mobility involves costs and benefits and that as costs increase for given benefits mobility will decrease. There would also be general agreement that there are significant transaction costs in the sale and purchase of a dwelling and owners may therefore be less inclined to look for employment opportunities outside the commuting range, as compared with renters. In addition, increasing duration of residence yields a nonpecuniary benefit in the form of attachment that tends to be greater for owners than renters as the former have a greater opportunity to modify the dwelling attributes (in terms of alterations, landscaping etc.) to suit individual tastes. These modifications are a type of location-fixed capital that is lost with a move.

Besides the plausible arguments why homeowners have lower migration rates (and are more likely to commute over longer distances) there is also plenty of international empirical evidence that confirms that migration rates among homeowners are lower, all else being equal (e.g., Much et al. 2006). The question is whether it is possible to identify an unbiased effect of ownership rates, via the mobility and job search effects, on the natural rate of unemployment.

Oswald (1996) simply considered bivariate correlations between unemployment rates and homeownership rates for (pooled) cross-sections of OECD countries, and regions in the US, UK, France, Italy and Sweden. He considers the evidence sufficiently robust to posit a stylized fact of a 1 percentage point increase in the rate of homeownership leading to a 0.2 percentage point increase in the unemployment rate. However, such an estimate is likely to be subject to omitted variable bias as there are various other determinants of a region's unemployment rate that are correlated with homeownership rates, such as the age structure and the average level of education of the population. The subsequent literature proceeded therefore along two lines: fully specified models of regional unemployment rates that include homeownership as a (possibly endogenous) covariate and micro-level research that investigates how homeownership can affect the likelihood of job quitting and search behaviour.

Figure 2: Home ownership and unemployment rates 16 Regional Council regions, 2006 census.

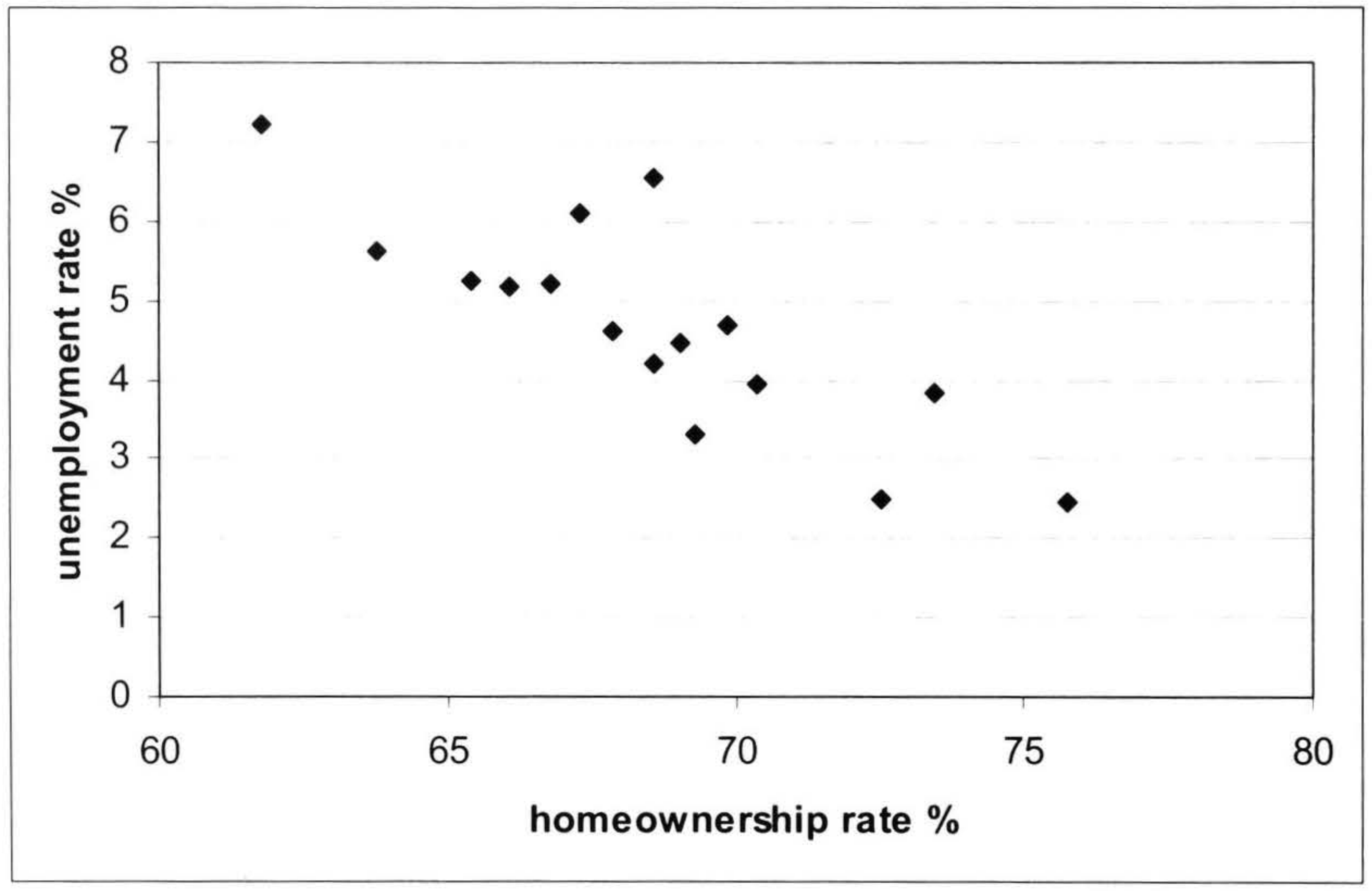

Sonrex: Statistics New Zealand. Census of Population and Duvellings 2006 
The macro-level studies initially supported the Oswald hypothesis (see Pehkonen (1997) using Finish regional data; Partridge and Rickman (1997) using US state data; and Nickell and Layard (1999) using OECD country data), but subsequent studies are less conclusive (e.g. Flatau et al. 2002, using Australian data) or even reject the hypothesis (e.g., Green and Hendershott 2001, using US data).

One explanation for differences between macro studies is the extent to which the data are driven by cross-sectional variation or by changes over time at given locations. It is plausible that the latter type of data are likely to yield an on average larger effect, as was confirmed by Oswald's original study (1996: 15). The reason is that crosssectional composition effects on the supply side, such as age and education, and labour demand effects (higher incomes in more prosperous regions) shift the regression coefficient in the opposite direction, suggesting an inverse relationship between a region's unemployment rate and the proportion of dwellings owner-occupied. In the New Zealand case, this is illustrated in Figure 2 that provides a cross-sectional scatter plot of unemployment rates and homeownership rates derived from recently released 2006 census data. The figure suggests a negatively sloped cross-sectional relationship across the 16 Regional Council regions. However, over time, all regions experienced qualitatively similar changes in homeownership rates and unemployment rates as displayed in Figure 1 at the national level (see Pool et al. 2005). Thus, results from regression modelling are likely to depend on, firstly, the extent to which the results are driven by cross-sectional versus time series variation and, secondly, the extent to which co-variates and the estimation technique is likely to account for omitted variable bias and causality that can run in both directions. The New Zealand evidence reported later takes these issues into account.

There is also a measurement issue with respect to homeownership that is important. Homeowners without mortgages have significant wealth and may search for jobs locally for longer than those whose mortgage repayment obligations lower their reservation wage (see e.g. Flatau et al. 2003 for Australian evidence and Goss and Phillips 1997 using US panel data). In addition, renters of public housing may lose their subsidy with migration and have therefore lower mobility than owners. Household structure matters too. Single persons are more likely to be in a rental (or "flatting" situation) and therefore less likely to have job search constrained by the "tied stayer" phenomenon (where a potential wage gain from migration would be more than offset by an implied wage loss for the partner).

The micro level research that followed the earlier macro level studies of the Oswald hypothesis have been specifically focussed on such issues as the impact of the type of ownership and the structure of households on quits and job search behaviour. These studies are also reviewed in Munch et al. (2006) and Rouwendal and Nijkamp (2006) and because the present paper is concerned with regional level macro data, we will not review these here. Rouwendal and Nijkamp (2006) conclude that the micro level studies almost unanimously reject the Oswald hypothesis. There is general empirical support for the idea that homeownership lowers geographic mobility but it does not logically follow that homeowners therefore experience longer unemployment spells. Instead, even controlling for human capital characteristics, homeowners appear to have higher exit rates from unemployment.

In conclusion, we note that there is some (but not uniform) support for the Oswald hypothesis at the macro level and yet the obvious explanation in terms of job search behaviour appears contradicted by micro level evidence. The questions is therefore (1) the extent to which the macro level evidence is spurious, or at least robust under a wide range of econometrics specifications, and (2) the need for a theoretical reconciliation of the macro and micro evidence. The latter has already been attempted by Dohmen (2005), but here we revisit the former issue with New Zealand data for Labour Market Areas.

\section{Data}

The data for our analysis were obtained from the quinquennial New Zealand Census of Population and Dwellings 1986 to 2001. The Labour Market Area (LMA) data have been built up from census area unit level and made available for this research by Motu Economic and Public Policy Research. It has long been recognised that functional economic areas are the most appropriate unit of analysis for examining regional economic activity (Stabler \& Olfert, 1996: 206) as administrative areas such as Regional Council regions or territorial authorities tend to be rather arbitrary in terms of their boundaries in so far as they are reflective of economic relations. Administrative areas have largely served as the basis for most regional analysis in the past as most official statistics have been gathered or aggregated to administrative boundaries. These days, however, it is possible to build up regional data with any defined boundaries from very small geographical units of measurement, using GIS and related systems.

Consequently, there has been growth in the use of functional economic areas, notably in the analysis of various labour market phenomena (see for instance (Casado-Diaz, 2000; Newell \& Papps, 2001; ONS \& Coombes, 1998; Watts, 2004). Newell and Papps (2001) used travel to work data from the 1991 and 2001 censuses to define LMAs in New Zealand. This research yielded 140 LMAs for 1991 and 106 for 2001. This level of breakdown is too refined for linking to regional characteristics that come from sources other than the census. A level of disaggregation that permits the building up of a regional analysis with a wide range of regional indicators is that of 58 LMAs. The boundaries and names of these LMAs are shown in Figure 3. A description of the data can be found in Table 1 . 
Figure 3: New Zealand Labour Market Areas 1986-2001.

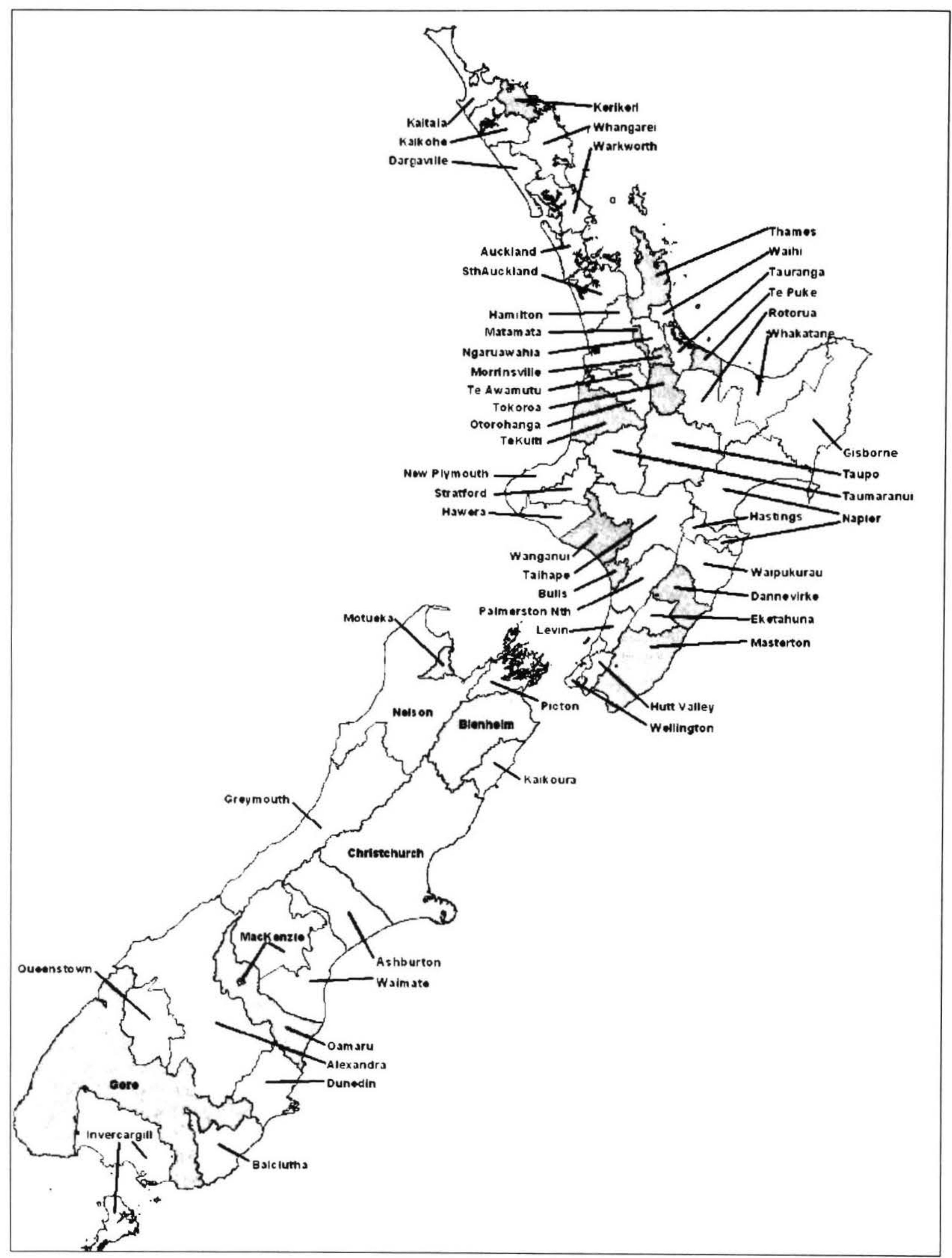

Source - Mare and Timmins (2004: 18) 
Table 1: Data Descriptives.

\begin{tabular}{|c|c|c|c|c|c|c|c|c|c|c|c|}
\hline & Year & Net Migration' $^{\prime}$ & Population $^{2}$ & $\begin{array}{c}\text { Home } \\
\text { Ownership }\end{array}$ & $\begin{array}{c}\text { Single Person } \\
\text { Household }\end{array}$ & $\begin{array}{c}\text { Over } 40 \\
\text { Population }\end{array}$ & $\begin{array}{c}\text { Maori } \\
\text { Population }^{6}\end{array}$ & $\begin{array}{c}\text { Asian } \\
\text { Population? }\end{array}$ & $\begin{array}{c}\text { Manual } \\
\text { Employment }\end{array}$ & Bartik Index & Unemployment $^{10}$ \\
\hline Mean & 1986 & $\mathrm{~N} / \mathrm{A}$ & 56260 & 71.56 & 18.05 & 34.21 & 15.10 & 0.74 & 13.28 & N/A & 6.74 \\
\hline Median & 1986 & N/A & 22749 & 72.45 & 18.17 & 33.91 & 12.09 & 0.53 & 13.39 & N/A & 6.67 \\
\hline S.D & 1986 & N/A & 93409 & 5.77 & 2.19 & 3.64 & 10.51 & 0.67 & 2.06 & N/A & 1.80 \\
\hline $\operatorname{Max}$ & 1986 & N/A & 514890 & 80.15 & 22.34 & 42.49 & 51.63 & 3.63 & 18.56 & N/A & 13.60 \\
\hline Min & 1986 & N/A & 3360 & 47.99 & 13.51 & 23.13 & 2.79 & 0.09 & 8.30 & N/A & 2.33 \\
\hline Mean & 1991 & -1.87 & 58168 & 72.52 & 20.14 & 37.31 & 16.19 & 1.19 & 11.60 & -7.96 & 10.38 \\
\hline Median & 1991 & -1.99 & 22002 & 73.29 & 20.27 & 37.03 & 12.54 & 0.78 & 11.58 & -8.39 & 10.02 \\
\hline S.D & 1991 & 7.11 & 99385 & 5.43 & 2.02 & 3.87 & 11.39 & 1.21 & 1.60 & 1.89 & 2.86 \\
\hline Max & 1991 & 21.75 & 552591 & 81.14 & 24.69 & 46.25 & 57.16 & 5.73 & 14.67 & -0.72 & 21.07 \\
\hline Min & 1991 & -22.07 & 3273 & 51.18 & 15.32 & 27.13 & 3.17 & 0.23 & 7.24 & -11.98 & 6.00 \\
\hline Mean & 1996 & -1.74 & 62383 & 70.03 & 21.08 & 39.97 & 18.39 & 1.66 & 13.23 & 14.94 & 7.51 \\
\hline Median & 1996 & -2.29 & 23634 & 70.63 & 21.03 & 39.49 & 15.17 & 0.98 & 13.13 & 14.34 & 7.07 \\
\hline S.D & 1996 & 8.76 & 111061 & 4.96 & 2.00 & 4.03 & 11.32 & 1.82 & 1.68 & 2.90 & 2.87 \\
\hline $\operatorname{Max}$ & 1996 & 41.14 & 629432 & 79.15 & 25.36 & 48.46 & 56.06 & 9.00 & 17.75 & 22.21 & 18.98 \\
\hline Min & 1996 & -17.06 & 3516 & 51.39 & 16.03 & 29.98 & 4.64 & 0.40 & 8.48 & 9.41 & 2.33 \\
\hline Mean & 2001 & -2.41 & 64433 & 69.78 & 24.46 & 44.36 & 18.25 & 2.08 & 13.94 & 4.06 & 7.00 \\
\hline Median & 2001 & -2.40 & 23519 & 70.50 & 24.60 & 44.44 & 15.09 & 1.18 & 13.63 & 3.98 & 6.36 \\
\hline S.D & 2001 & 6.56 & 119230.1 & 4.35 & 2.14 & 4.47 & 11.46 & 2.45 & 1.98 & 1.90 & 2.88 \\
\hline $\operatorname{Max}$ & 2001 & 16.47 & 680547 & 77.80 & 28.79 & 55.70 & 57.88 & 12.84 & 18.58 & 9.40 & 17.99 \\
\hline Min & 2001 & -19.64 & 3483 & 55.12 & 17.79 & 36.34 & 4.47 & 0.41 & 9.34 & 0.36 & 2.51 \\
\hline
\end{tabular}

Net intercensal migration rate calculated by census survivorship method - see Baxendine et al (2005) for details

The census usually resident population of an LMA

The proportion of owner-occupied dwellings in the LMA

The proportion of the population aged 40 years and over in the LMA

The proportion of an LMA's population with Maori ethnicity

The proportion of an LMA's population with Asian ethnicity

The proportion of the LMA's employment in manual occupations

Predicted growth (\%) in employment based on the LMA's sectoral composition

Those aged 15 and over who are unemployed as a percentage of the LMA's labour force 


\section{Pooled Cross-Sectional Results}

As a first step in our analysis we conducted a standard pooled OLS regression on the LMA unemployment rate, the results being shown in Table 2. To avoid the problem of reverse causality, we lag those variables that are likely to be affected by unemployment. These variables are homeownership and the proportion of single person households. The justification for the latter is that economic hardship may lead to marriage breakdown. For these two variables, values at the previous census are used. The Bartik index of predicted employment growth based on sectoral structure and the net migration rate are calculated over the preceding intercensal period. Consequently, with 58 LMAs and data from 1986 until 2001, we have 174 observations.

Most variables have plausible coefficients. The unemployment rate is less in LMAs with a favourable sectoral structure (as indicated by the Bartik index) and where the population is relatively older. LMAs with larger proportions of Maori and Asian workers, or with larger proportions of single person households, have higher unemployment rates. However, unemployment rates are lower in LMAs with a relatively large proportion of workers in manual occupations. Net intercensal inward migration is an indicator of greater labour market churning and increases the unemployment rate. With respect to the homeownership rate, the results confirm the Oswald hypothesis and the coefficient $(0.35)$ is in fact considerably larger than the typical value suggested by Oswald (0.2).

Table 2 also reports some diagnostics commonly used to identify misspecification in OLS cross-sectional models. The Jarque-Berra test is far from significant indicating that we can have confidence that the OLS estimate errors are normally distributed while the Breusch-Pagan statistic and robust White statistic give us no cause to reject the assumption of homoscedasticity.

However, the OLS results are likely to be biased. Not all factors determining differences in unemployment across regions are likely to be observed. As some of the omitted variables are likely to be correlated with the included variables, OLS will yield biased parameter estimates. By exploiting the panel structure of the data (the repeated observations on regions over time), we can to some extent resolve the missing variables problem. We can then also take into account that the impact of a determinant of unemployment changing over time within a region may be different from the impact of the same determinant changing cross-sectionally relative to other regions

Table 2: Ordinary Least Squares Estimates.

\begin{tabular}{|c|c|c|c|}
\hline R-squared & 0.7511 & & \\
\hline Adjusted R-squared & 0.7391 & & \\
\hline$\hat{\sigma}^{2}$ & 2.7024 & & \\
\hline $\begin{array}{l}\text { Number of observations (58 LMAs: } 1991 . \\
1996 \text { and 2001) }\end{array}$ & 174 & & \\
\hline \multicolumn{4}{|c|}{ - } \\
\hline Variable & Coefficient & t-statistic & P-value \\
\hline $\begin{array}{l}\text { The proportion of owner occupied dwellings at } \\
\text { previous census }\end{array}$ & 0.3550 & 11.92 & 0.000 \\
\hline Bartik index & -0.1417 & -8.75 & 0.000 \\
\hline $\begin{array}{l}\text { The proportion of single person households at } \\
\text { previous census }\end{array}$ & 0.3207 & 3.75 & 0.000 \\
\hline $\begin{array}{l}\text { The proportion of the population aged } 40 \text { and } \\
\text { over }\end{array}$ & -0.4030 & -7.85 & 0.000 \\
\hline $\begin{array}{l}\text { The proportion of the population of Maori } \\
\text { ethnicity }\end{array}$ & 0.2395 & 16.72 & 0.000 \\
\hline $\begin{array}{l}\text { The proportion of the population of Asian } \\
\text { ethnicity }\end{array}$ & 0.2298 & 2.25 & 0.026 \\
\hline $\begin{array}{l}\text { The proportion of employment in manual } \\
\text { occupations }\end{array}$ & -0.1992 & -2.54 & 0.012 \\
\hline Intercensal net migration & 0.1288 & 6.31 & 0.000 \\
\hline Constant & -9.3260 & -4.11 & 0.000 \\
\hline \multicolumn{4}{|c|}{ 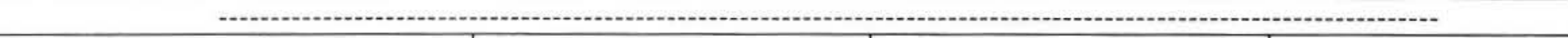 } \\
\hline \multicolumn{4}{|c|}{\begin{tabular}{|l|l|l|l|} 
Test on normality of errors & & &
\end{tabular}} \\
\hline Jarque-Bera & & Chi-sq (2) & $P$-value $=0.204$ \\
\hline \multicolumn{4}{|c|}{ Diagnostics for homoscedasticity } \\
\hline Breusch-Pagan & & Chi-sq (8) & P-value $=0.158$ \\
\hline White & & Chi-sq (44) & P-value $=0.410$ \\
\hline
\end{tabular}




\section{Panel Models}

To improve on the estimates obtained by OLS we performed fixed and random effects estimations. The standard test for differentiating between fixed and random effects, the Hausman specification test (e.g., Baltagi et al. 2003: 362), was performed, finding that the fixed effects model was appropriate in this instance. The results for the fixed effects estimator are shown in Table 3 . It should be noted that, notwithstanding the results of a Hausman test, the random effects specification is arguably inappropriate in this instance as we are not concerned with a random draw of spatial units from an asymptotically infinite population but rather an exhaustive sampling (Nerlove \& Balestra, 1996: 4) of LMA's in New Zealand and the effects that are in this particular sample.

From the fixed effects results (see Table 3 ) we see that the coefficient on the homeownership variable takes the expected sign, is statistically significant and has a magnitude similar to that found by Oswald though it is around a third smaller than that obtained by the pooled OLS estimator. Of the other variables only those for expected employment growth, the proportion of the population aged 40 years and over, and net-migration remain significant at traditional levels. This suggests that the other variables (ethnicity, household types and occupational distribution) contribute to explaining the cross-sectional variation in unemployment rates, but not to the changes within LMAs over time. Their impact is in a sense now "embodied" in the regional fixed effects.

In order to exploit the statistical advantages of the fixed effects estimator, while also identifying separately the roles of various cross-sectional factors, Hausman and Taylor (1981) proposed a so-called instrumental variable estimator which uses both the 'between' and 'within' variation of the strictly exogenous variables as instruments, in which some of the regressors are correlated with LMA fixed effects (Baltagi, 2005). Given the expected impact of ethnicity on cross-sectional variation in unemployment rates, we include here the average proportion of the population who are classified as Maori 1986-2001, and the corresponding average proportion of the population who are classified as Asian 1986-2001 in the model as time-invariant (because of the averaging over time) exogenous variables. Homeownership is assumed to be the time-variant endogenous variable. Table 4 shows the results for the Hausman Taylor estimator. These results generally reconfirm the earlier results. The coefficient on the homeownership variable $(0.2748)$ is of the correct sign, significant and intermediate between the estimates obtained by pooled OLS and fixed effects estimators. Of the other variables included in the model, all are statistically significant with the exception of those for the proportion of single person households and the average proportion of Asian persons.

Table 3: Fixed Effects Panel Model Estimates.

\begin{tabular}{|c|c|c|c|}
\hline R-squared within & 0.9051 & & \\
\hline R-squared between & 0.3565 & & \\
\hline R-squared overall & 0.4730 & & \\
\hline $\begin{array}{l}\text { F test that all fixed effects are zero } \\
F(57,108)\end{array}$ & 18.44 & Prob $>F=0.000$ & \\
\hline $\begin{array}{l}\text { Number of observations (58 LMAs; } 1991 \text {, } \\
1996 \text { and 2001) }\end{array}$ & 174 & & \\
\hline \multicolumn{4}{|c|}{ (2) } \\
\hline Variable & Coefficient & t-statistic & P-value \\
\hline $\begin{array}{l}\text { The proportion of owner occupied dwellings } \\
\text { at previous census }\end{array}$ & 0.2374 & 4.81 & 0.000 \\
\hline Bartik index & -0.0935 & -9.41 & 0.000 \\
\hline $\begin{array}{l}\text { The proportion of single person households at } \\
\text { previous census }\end{array}$ & 0.0827 & 0.85 & 0.397 \\
\hline $\begin{array}{l}\text { The proportion of the population aged } 40 \text { and } \\
\text { over }\end{array}$ & -0.4090 & -7.13 & 0.000 \\
\hline $\begin{array}{l}\text { The proportion of the population of Maori } \\
\text { ethnicity }\end{array}$ & 0.0617 & 0.95 & 0.344 \\
\hline $\begin{array}{l}\text { The proportion of the population of Asian } \\
\text { ethnicity }\end{array}$ & 0.0636 & 0.67 & 0.506 \\
\hline $\begin{array}{l}\text { The proportion of employment in manual } \\
\text { occupations }\end{array}$ & -0.0344 & -0.56 & 0.576 \\
\hline Intercensal net migration & 0.0513 & 2.70 & 0.008 \\
\hline Constant & 4.7062 & 1.16 & 0.247 \\
\hline
\end{tabular}


Table 4: Hausman-Taylor Panel Model Estimates.

\begin{tabular}{|c|c|c|c|}
\hline Pseudo R-squared & 0.8442 & & \\
\hline Wald chi-squared (7) & 1149.08 & Prob $>X 2=0.000$ & \\
\hline $\begin{array}{l}\text { Number of observations (58 LMAs: } 1991 \text {, } \\
1996 \text { and 2001) }\end{array}$ & 174 & & \\
\hline \multicolumn{4}{|c|}{ 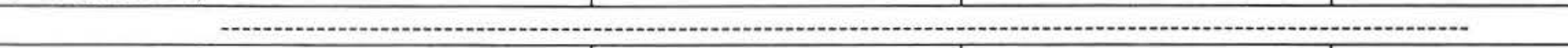 } \\
\hline Variable & Coefficient & t-statistic & P-value \\
\hline \multicolumn{4}{|l|}{ Time-variant exogenous } \\
\hline Bartik Index & -0.0968 & -14.62 & 0.000 \\
\hline $\begin{array}{l}\text { The proportion of single person households } \\
\text { at previous census }\end{array}$ & 0.1004 & 1.32 & 0.186 \\
\hline $\begin{array}{l}\text { The proportion of the population aged } 40 \\
\text { and over }\end{array}$ & -0.3542 & -8.93 & 0.000 \\
\hline Intercensal net migration & 0.0542 & 3.48 & 0.001 \\
\hline \multicolumn{4}{|l|}{ Time-1'ariant endogenous } \\
\hline $\begin{array}{l}\text { The proportion of owner occupied } \\
\text { dwellings at previous census }\end{array}$ & 0.2748 & 8.36 & 0.000 \\
\hline \multicolumn{4}{|l|}{ Time-invariamt exogenous } \\
\hline $\begin{array}{l}\text { The proportion of the population of Maori } \\
\text { ethnicity }\end{array}$ & 0.2139 & 8.87 & 0.000 \\
\hline $\begin{array}{l}\text { The proportion of the population of Asian } \\
\text { ethnicity }\end{array}$ & 0.234 & 1.37 & 0.172 \\
\hline Constant & -3.636 & -1.21 & 0.228 \\
\hline
\end{tabular}

\section{Future Research}

This paper has focussed on the macro level investigation of the relationship posited by Oswald between housing tenure and unemployment. This research maybe expanded in a number of ways.

Firstly, housing tenure is not merely a dichotomy between ownership and non-ownership. There exist a number of gradations between owning a dwelling outright and renting accommodation. For instance, a dwelling might be owned outright or with a mortgage, which may be more or less highly leveraged. Similarly those renting accommodation may be renting in an unregulated housing market or they may receive state subsidies, enjoy nonmarket rents in state provided accommodation or even receive gratis accommodation from family or employers. Future research will include these gradations of tenure and examine their impact upon both geographic mobility and unemployment.

Secondly, the analysis presented here ignores the inherently spatial nature of the data used. Should there be significant levels of spatial autocorrelation present in the data (and the findings of Cochrane and Neilson (2005) with respect to unemployment would suggest this maybe the case in New Zealand), the use of OLS and non-spatial panel models may result in biased parameter estimates and a flawed analysis (O'Sullivan \& Unwin, 2003: 2830). Exploratory spatial econometric modelling with the same data as used for the present analysis shows that spatial models are indeed needed to accurately estimate the effect of homeownership on unemployment. However, as will be reported in a subsequent paper, the results do suggest that the positive relationship between unemployment rates and homeownership rates at the LMA level is robust. Moreover, the relationship has a coefficient that is close to the typical value found by Oswald $(0.2)$.
Thirdly, the analysis conducted here is at a macro level. Such studies have frequently been more optimistic, particularly in the earlier literature, in their assessment of the tenability of Oswald's hypothesis than those using micro data. It is the intention to continue our investigation of Oswald's hypothesis through the use of micro data. Census micro data, Household Labour Force Survey or the Survey of Families, Income and Employment (SoFIE) would all seem to be worthy of investigation (unfortunately, the Linked Employee Employer Data (LEED) lack the necessary variables to use these data). It would be advantageous for our analysis if the data contained micro labour turnover data that gave us information on voluntary quits, unemployment spells and housing tenure type and length.

\section{Conclusion}

This paper has presented evidence that is highly supportive of Oswald's contention that there is a causal link between the prevalence of homeownership and the unemployment rate, namely that higher levels of homeownership are associated with higher levels of unemployment.

The parameter estimates for the homeownership variable obtained by both the fixed effects and Hausman Taylor estimators were of similar magnitude to that obtained by Oswald. The OLS estimator gives a markedly higher coefficient that would seem rather implausible. Taking the relatively conservative FE estimates as a benchmark, the results suggest that, ceteris parihus, a 1 percentage point decline in the level of homeownership would induce a decline in the unemployment rate of between 0.14 and 0.34 percentage points ( 95 percent confidence interval). Placing this in historical context, the census homeownership rate in New Zealand declined from 74 percent in 1991 to 67 percent in 2006, a fall of 7 
percentage points. Unemployment fell also by around 7 percentage points over the same period. The econometric estimates reported here suggest that the decline in homeownership alone would have contributed a 1.0 to 2.4 percentage points decline in the unemployment rate, which is not an insubstantial effect.

While the evidence presented in this paper would seem to indicate that declines in the level of homeownership have increased labour market flexibility, and hence promoted a decline in unemployment, this analysis is by no means intending to suggest that low levels of homeownership ought to be a policy goal. Homeownership serves many purposes in our society, for instance it has been seen as the 'hidden' cornerstone (Castles, 1994) of Australasian welfare systems, particularly in respect to the provision of adequate retirement incomes and a key means of intergenerational transmission of wealth (Arcus and Nana, 2005). Perhaps more fundamentally, as Skilling (2004) has argued, asset ownership, and in particular homeownership, plays a fundamental integrative function in society as it not only enhances individual security but, when ownership is widely diffused through out society, fosters a cohesive society.

\section{References}

Arcus, M., and Nana, G. (2005). Centre for Housing Research Aotearoa New Zealand. Wellington: Centre for Housing Research Aotearoa New Zealand.

Baltagi, B. H. (2005). Econometric analysis of panel data (3rd ed.). Chichester: John Wiley \& Sons.

Baltagi, B. H., et al. (2003). Fixed effects, random effects or Hausman-Taylor? A pretest estimator. Economics Letters, 79(3), 361-369.

Baxendine, S., Cochrane, W. and Poot, J. (2005) Description and Spatial Analysis of Employment Change in New Zealand Regions 1986-200I (Discussion paper No. 57). Hamilton: Population Studies Centre, University of Waikato.

Casado-Diaz, J. M. (2000). Local Labour Market Areas in Spain. Regional Studies, 34(9), 843-856.

Castles, F. (1994). The Wage earners welfare state revisited. Australian Journal of Social Issues. 29(2), 120-145.

Cochrane, W., and Neilson, D. (2005). An exploratory spatial data analysis of unemployment in New Zealand 1986-2001. In G. Wrightson (Ed.), Procedings of the Creating a Culture of Full Employment Conference, University of Newcastle, 8-9 December 2005. Newcastle, NSW: University of Newcastle.

Dohmen, T.J. (2005) Housing, Mobility and Unemployment. Regional Science and Urban Economics, 35, 305-325.
Evans, L., Grimes, A., Wilkinson, B., \& Teece, D. (1996). Economic Reform in New Zealand 1984-95: The pursuit of efficiency. Journal of Economic Literature, 34, 1856-1902.

Flatau, P., Forbes, M., Wood, G., Hendershott, P.H. and L. O'Dwyer (2002). Home Ownership and Unemployment: Does the Oswald Thesis Hold for Australian Regions? (Working paper No. 189): Murdoch University.

Flatau, P., Forbes, M., Hendershott, P.H. and Wood, G. (2003). Homeownership and Unemployment: the Roles of Leverage and Public Housing. NBER Working Paper 10021, National Bureau of Economic Research, Cambridge MA 02138.

Goss, E.P. and Philips, J.M. (1997). The Impact of Home Ownership on the Duration of Unemployment. Review of Regional Studies, 27(1): 9-27.

Glaeser, E., and Shapiro, J. (2002). The Benefits of the Home Mortgage Interest Deduction (Working Paper No. 9284): NBER.

Green, R. and Hendershott, P. (2001) Home Ownership and Unemployment in the US. Urban Studies, 38, 1501-1520.

Gorter, C. and Poot, J. (1999) Measuring the Impact of Labour Market Deregulation. In: G. Crampton (ed.) Research in Labour Economics. Advances in European Research in Regional Science, Volume 9. Pion, London, pp. 63-90.

Hausman, J. A., and Taylor, W. E. (1981). Panel data and unobservable individual effects. Econometrica, 49, 1377-1398.

Maré, D., \& Timmins, J. (2004). Internal Migration and Regional Labour Markets in New Zealand (Unpublished draft). Wellington: Motu: Economic and Public Policy Research Trust.

Munch, J.R., Rosholm, M., Svarer, M. (2006) Are Homeowners Really More Unemployed? The Economic Journal 116 (October): 991-1013.

Nerlove, M., \& Balestra, P. (1996). Formulation and Estimation of Econometric Models for Panel Data. In L. Ma'tya's \& P. Sevestre (Eds.), The Econometrics of Panel Data (2nd revised edition ed.). Kluwer: Dordrecht, The Netherlands.

Newell, J., \& Papps, K. (2001). Identifving Functional Labour Market Areas in New Zealand: A Reconnaissance Study using Travel-to-Work Data (New Zealand Department of Labour Occasional Paper Series No. 2001/6). Wellington: Department of Labour. 
Nickell, S. and Layard, R. (1999) Labour Market Institutions and Economic Performance. In A. Ashenfelter and D. Card (eds) Handbook of Labor Economics, Amsterdam: North-Holland, 3029-3084.

ONS, and Coombes, M. G. (1998). 1991- Travel to Work Areas. London: Office for National Statistics.

O'Sullivan, D., and Unwin, D. (2003). Geographic Information Analysis. New Jersey: John Wiley \& Sons, Inc.

Oswald, A. (1996) A Conjecture on the Explanation for High Unemployment in the Industrialized Nations: Part I. Warwick University Economic Research Paper No. 475.

Oswald, A. (1997a) Theory of Homes and Jobs. Mimeo. Warwick University.

Oswald, A. (1997b) Thoughts on NAIRU. Journal of Economic Perspectives, 11(1), 227-228.

Oswald, A. (1999) The Housing Market and Europe's Unemployment: A Non-Technical Paper. Mimeo. Warwick University.

Partridge, M.D., and Rickman, D.S. (1997) The Dispersion of US State Unemployment Rates: The Role of Market and Non-market Equilibrium Factors. Regional Studies, 31, 593606.

Pehkonen, J. (1997) Unemployment and Homeownership. Applied Economic Letters 6, 263-265.

Pool, I., Baxendine, S., Cochrane, W. and Lindop, J. (2005) New Zealand Regions, 1986-2001: Households and Families, and their Dwellings. PSC Discussion Paper No 55, Population Studies Centre, University of Waikato.
Rouwendal, J. and Nijkamp, P. (2006) Homeownership and Labour Market Behaviour: Interpreting the Evidence. mimeo. Free University Amsterdam.

Skilling, D. (2004). It's not just about the money: the benefits of asset homeownership. Auckland: The New Zealand Institute.

Stabler, J. C., and Olfert, M. R. (1996). Spatial labor markets and the rural labor force. Growth \& Change, 27(2), 206-230.

Stock, J. H., and Watson, M. W. (2003). Introduction to econometrics. Boston, MA: Addison Wesley.

Watts, M. (2004). Local Labour Markets in New South Wales: Fact or Fiction? (Working Paper No. 0412). Newcastle, NSW: Centre of Full Employment and Equity, University of Newcastle.

\section{Authors}

William Cochrane

Research Consultant

Population Studies Centre

University of Waikato

Private Bag 3105

Hamilton

BillC@waikato.ac.nz

Jacques Poot

Director

Population Studies Centre

University of Waikato

Private Bag 3105

Hamilton

JPoot@waikato.ac.nz 